\title{
Epidemiology of Intraspecies Bite Wounds in Dogs in the Czech Republic
}

\author{
E. BARANYIOVÁ ${ }^{1,2}$, A. HOLUB, M. MARTINÍKOVÁ ${ }^{1}$, A. NEČAS ${ }^{3}$, J. ZATLOUKAL $^{3}$ \\ ${ }^{1}$ Department of Veterinary Public Health and Forensic Medicine, Faculty of Veterinary Hygiene and Ecology, \\ University of Veterinary and Pharmaceutical Sciences and ${ }^{2}$ Veterinary Research, Institute, Brno, \\ ${ }^{3}$ Small Animal Clinic, Department of Surgery and Orthopedics, Faculty of Veterinary Medicine, \\ University of Veterinary and Pharmaceutical Sciences, Brno, Czech Republic \\ Received September 13, 2002 \\ Accepted March 25, 2003

\section{Abstract} \\ Baranyiová, E., A. Holub, M. Martiníková, A. Nečas, J. Zatloukal: Epidemiology \\ of Intraspecies Bite Wounds in Dogs in the Czech Republic. Acta Vet. Brno 2003, 72: 55-62. \\ The epidemiology of bite wounds in dogs that resulted from intraspecies conflicts and were treated \\ at the Small Animal Clinic, Department of Surgery and Orthopedics, University of Veterinary and \\ Pharmaceutical Sciences, Brno was evaluated from 246 records in 1989-90 and 337 records in 1998- \\ 99. The number of bite incidents fluctuated during the year. The majority of incidents occurred in \\ summer months, i.e. in the second $(n=149)$ and third $(n=193)$ trimester of the year. In comparison, \\ only 119 and 122 bite victims were treated in winter months, i.e. in the first and fourth trimester, \\ respectively. The total number of bite victims increased $(p<0.01)$ between the first and the second \\ period under study. Most treated dogs belonged to small (37.9\%), and large (24.8\%) breeds, followed \\ by medium-sized $(19.0 \%)$, giant $(11 \%)$ and toy breeds $(7.3 \%)$. A high proportion of the victims were \\ 1 year $(11.4 \%)$ and 2 years $(15.6 \%)$ of age, and the proportion decreased with age down to $1 \%$ at 11 \\ years. Also, there were indicators for a sex effect. Of the 571 cases where the dog's sex was recorded \\ 176 concerned a female $(30.3 \%)$ and $405(69.7 \%)$ a male. For 503 dogs the positions of the wounds \\ were recorded. A large portion of the wounds was administered to the thorax $(26.6 \%)$ and head \\ $(24.30 \%)$, i.e. the frontal body parts. More than one fourth of all head wounds were in the relatively \\ small areas around the eyes $(28.7 \%)$. Fewer bites were on the limbs $(17.7 \%)$, neck $(17.3 \%)$ and in the \\ abdominal regions $(14.3 \%)$. These data suggest that for dogs the risk of being wounded by a \\ conspecific differs between seasons and depends on a dog's age, sex and body size. \\ Epidemiology, dog bites, age, sex, body size, season, injury location
}

One of the main risk factors in the coexistence of humans and dogs is canine agonistic behaviour, i.e. appropriate but also inappropriate threats or challenges resolved by aggression or submission. Biologically, "normal aggression" aims at increasing the distance in time and space to an opponent, and it is a means to an end in a conflict over resources (Schoening 2001). Aggression constitutes various proportions of dog behaviour problems; between 18.6\% (Beaver 1994) and 62\% (Mertens and Dodman 1996).

Earlier views, even if sometimes not clearly formulated, suggested that aggression is a unitary phenomenon (Azrin et al. 1965; Lorenz 1966). Nowadays this simplistic idea is accepted less frequently (Hetts et al. 1992; Houpt and Willis 2001) but as stated by Fraser and Rushen (1987), it still survives. Presently, the circumstances under which aggression occurs become more emphasized. Dogs attacking in one situation may behave quite differently in another, though similar, situation (Serpell and Jagoe 1995). The problem of evaluating aggression is further complicated by the fact that its definition (Borchelt 1983; Askew 1997; Overall 1997; Houpt and Willis 2001) and methods of its classification are often disparate (Serpell and Jagoe 1995) and so aggression continues to be connected with myths, anthropomorphism and misunderstandings (Overall 1997).

Aggressive dogs are mostly characterized as dominant or protective of household members and items (Serpell and Jagoe 1995; Askew 1997). Occurrence of this 
undesirable dog behaviour is often connected with specific breeds (Coppinger and Schneider 1995; Houpt and Willis 2001) and sex. According to some authors, males tend to be aggressive more often than females (e.g. Beaver 1983; Hart and Hart 1985; Serpell 1995b; Willis 1995; Landsberg and Ruehl 1997; Overall 1997; Podberscek et al. 1999). Aggression also changes with age, it undergoes individual development (e.g. Serpell and Jagoe 1995; Houpt and Willis 2001).

The victims of dog aggression resulting in bites are not only people (it is estimated that more than four million people, adults and children, are bitten by dogs in the United States of America each year; Rapley et al. 2001) but also other animal species (Beaver 1983, 1993ab; Blackshaw 1988), including dogs despite their relatively lower intraspecies aggression (Lockwood 1995).

Mutual dog attacks may result in serious damage that requires medical intervention. Although analyses of intraspecies bites in dogs are available (Hart and Hart 1985; Sherman et al. 1996; Roll and Unshelm 1997; Griffin and Holt 2001; Shamir et al. 2002), there are still aspects of the problem that deserve attention (such as the long-term epidemiology of bite incidents). In this retrospective study we analyzed data about victims of aggression between dogs in terms of bite wounds recorded during two two-year periods ten years apart.

\section{Materials and Methods}

Information about dog bites was collected from the ambulance records of the Small Animal Clinic, Department of Surgery, University of Veterinary and Pharmaceutical Sciences in Brno, Czech Republic. However, in these records, no attempt was made to elucidate the circumstances of the conflicts between dogs. We processed records from the end of the $9^{\text {th }}$ and $10^{\text {th }}$ decade of the last century. In the first period, 1989 and 1990 , a total of 246 bitten dogs were treated, and in the second (1998 and 1999), 337 dogs bitten by other dogs were treated. Data about 583 dogs injured by other dogs were thus evaluated. Multiple injuries were recorded as well.

The dogs were divided into five size categories (Lew is et al. 1992) based on their breed: toy, small, medium, large and giant. Mixed-breed dogs were included into the respective groups by their body mass whenever possible. Statistical significance of differences was evaluated using $\chi^{2}$ test (Matoušková et al. 1992).

\section{Results}

In the course of both evaluated periods the number of dogs bitten during seasons of the year was changing. In Table 1, a breakdown of animals for the two periods under study is given, in Fig. 1

Table 1

Numbers of bitten dogs treated at the Small Animal Clinic $(\mathrm{n}=583)$

\begin{tabular}{|l|c|c|}
\hline Months & Years & Years \\
& $1989-1990$ & $1998-1999$ \\
\hline January & 13 & 19 \\
February & 18 & 18 \\
March & 26 & 25 \\
Total & 57 & 62 \\
\hline April & 22 & 32 \\
May & 21 & 34 \\
June & 19 & 21 \\
Total & 62 & 87 \\
\hline July & 25 & 48 \\
August & 26 & 36 \\
September & 21 & 37 \\
Total & 72 & 121 \\
\hline October & 18 & 28 \\
November & 16 & 11 \\
December & 21 & 28 \\
Total & 55 & 67 \\
\hline
\end{tabular}




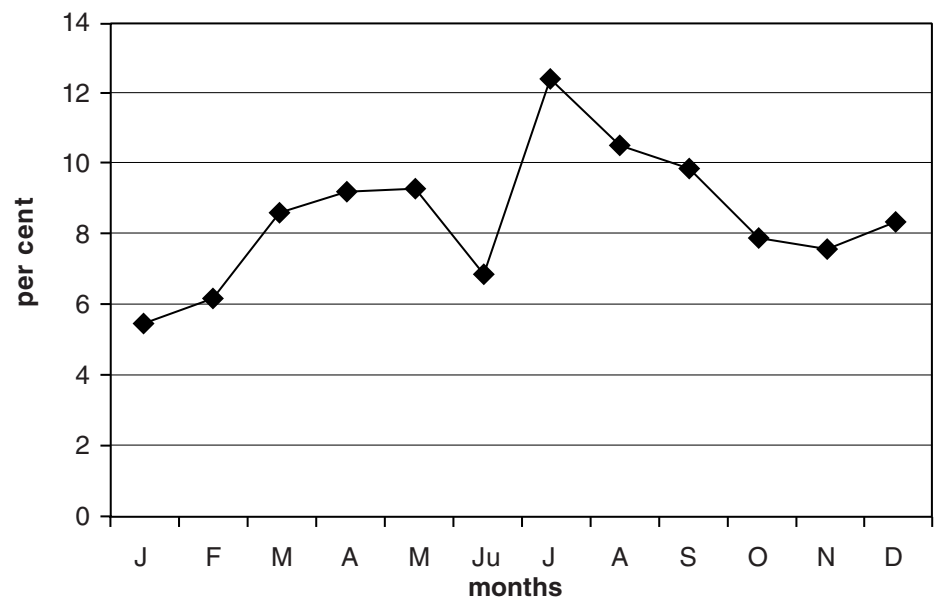

Fig. 1. Distribution of dog bite wounds over the year (1998-1999 and 1998-1999)

all dogs are included. The number of victims was highest in the third trimester (193), surpassing one third of the annual mean numbers (33.1\%). In the second trimesters, there were significantly fewer bite victims $(149 ; \mathrm{f}=6.274, p<0.05)$, and their number corresponded almost exactly to one quarter of the yearly mean numbers (25.6\%). Even fewer victims were recorded in the fourth (122, $\mathrm{f}=17.578, p<0.05)$ and the first trimesters $(119, \mathrm{f}=19.270, p<0.01)$. These numbers were only about one fifth of the annual mean numbers (20.4 and 20.9\%); differences between the second and first or fourth trimesters as well as between the first and fourth trimesters were not significant. The course of the changes was similar for both periods under study. The total number of bite victims increased by $37 \%$ between the first and the second period under study $(\mathrm{f}=28.408, p<0.01)$.

Table 2

Distribution of bitten dogs by size

\begin{tabular}{|c|c|c|c|c|}
\hline \multirow{2}{*}{ Size } & \multicolumn{2}{|c|}{$\begin{array}{c}\text { Years } \\
1989-1990\end{array}$} & \multicolumn{2}{|c|}{$\begin{array}{c}\text { Years } \\
1998-1999\end{array}$} \\
\hline & No. & $\%$ & No. & $\%$ \\
\hline Toy $(<5 \mathrm{~kg})$ & 10 & 5.3 & 25 & 8.6 \\
\hline Small $(5-10 \mathrm{~kg})$ & 102 & 54.0 & 80 & 27.5 \\
\hline Medium $(10-17 \mathrm{~kg})$ & 26 & 13.8 & 65 & 22.3 \\
\hline Large $(17-33 \mathrm{~kg})$ & 48 & 25.4 & 71 & 24.4 \\
\hline Giant (> $33 \mathrm{~kg})$ & 3 & 1.6 & 50 & 17.2 \\
\hline
\end{tabular}

We were further interested in body mass, i.e size of the bite victims. We included a total of 480 dogs with recorded body mass, 189 in 1989 to 1990, and 291 in 1998 to 1999, respectively. In Table 2, a breakdown of dogs for the periods under study is presented. Most treated dogs (182) belonged to small breeds, followed by significantly fewer large breed dogs $(119 ; \mathrm{f}=19.209, p<0.01)$. The number of medium-size dogs was even smaller $(91 ; \mathrm{f}=4.779$, $p<0.05)$. Significantly fewer than medium were giant breed dogs $(53$ animals, $(\mathrm{f}=11,616$, $p<0.01$ ). Toy breed dogs were bitten least frequently with 35 victims ( $\mathrm{f}=4,051, p<0.05)$.

Great sex differences were found in the numbers of bite victims (a total of only 176 females $(30.3 \%)$ versus 405 males $(69.7 \%)$, this difference was highly significant ( $\mathrm{f}=$ $180.520, p<0.01)$. In Table 3 , a breakdown by periods of study is given. No sex was recorded in two animals. 
Table 3

Sex of bitten dogs

\begin{tabular}{|c|c|c|c|c|}
\hline \multirow{2}{*}{ Sex } & \multicolumn{2}{|c|}{$\begin{array}{c}\text { Years } \\
1989-1990\end{array}$} & \multicolumn{2}{|c|}{$\begin{array}{c}\text { Years } \\
1998-1999\end{array}$} \\
\hline & No. & $\%$ & No. & $\%$ \\
\hline Females & 77 & 31.6 & 99 & 29.4 \\
\hline Males & 167 & 68.4 & 238 & 70.6 \\
\hline
\end{tabular}

Remarkable differences were found in the age of bitten dogs (Fig. 2). Among 571 individuals with age recorded at the time of treatment, the most frequently treated patients were two-year-old (89 animals). There were fewer one-year-old dogs $(65 ; \mathrm{f}=4.323, p<$ 0.05 ). The number of bitten dogs continued to decrease with advancing age so that with 6year-old animals this decrease became significant $(53 ; \mathrm{f}=10.423, p<0.01)$.

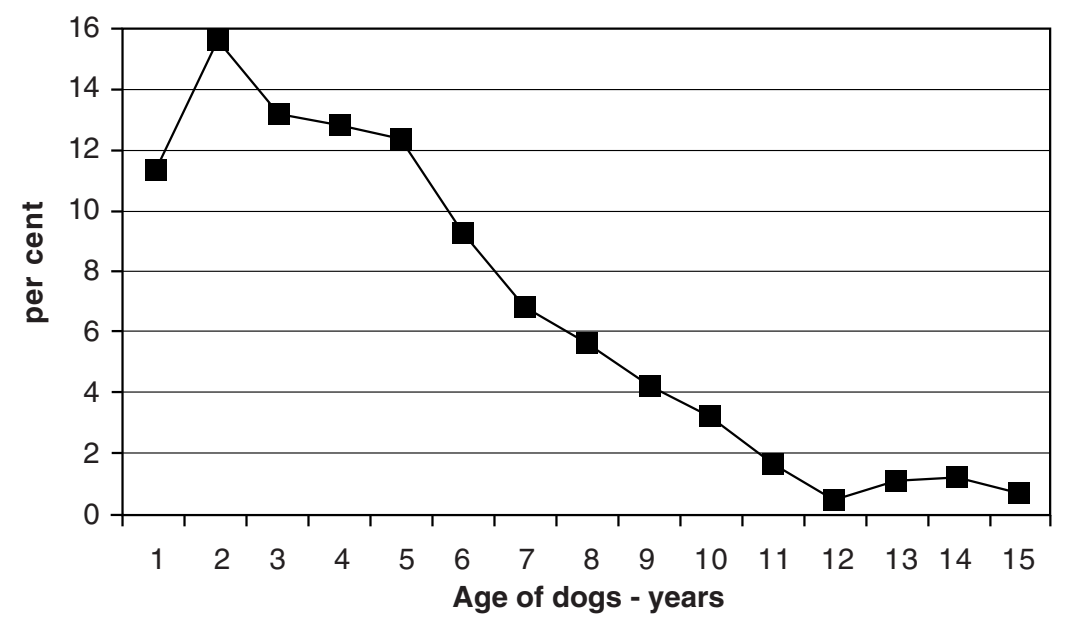

Fig. 2. Age of dog bite victims (1998-1999 and 1998-1999)

Location of bites was followed, too. In Table 4, a breakdown by periods under study is presented. Among 503 bite injuries with recorded location, most (133) were placed in the thoracic region $(26.6 \%)$, followed by those inflicted to the head region $(122 ; 24.3 \%)$. Here, ears were bitten in 46 victims $(9.1 \%)$ and eyelids in 35 victims $(7.0 \%)$. Thus more than one

Table 4

Location of wounds

\begin{tabular}{|c|c|c|c|c|}
\hline \multirow[t]{2}{*}{ Body region } & \multicolumn{2}{|c|}{$\begin{array}{c}\text { Years } \\
1989-1990\end{array}$} & \multicolumn{2}{|c|}{$\begin{array}{c}\text { Years } \\
1998-1999\end{array}$} \\
\hline & No. & $\%$ & No. & $\%$ \\
\hline Head & 48 & 18.6 & 74 & 30.2 \\
\hline Auricles & 17 & 6.6 & 29 & 11.8 \\
\hline Eyelids & 12 & 4.7 & 23 & 9.4 \\
\hline Thorax & 81 & 31.4 & 52 & 21.2 \\
\hline Neck & 44 & 17.1 & 43 & 17.6 \\
\hline Limbs & 46 & 17.8 & 43 & 17.6 \\
\hline Abdomen & 39 & 15.1 & 33 & 13.5 \\
\hline
\end{tabular}


fourth of wounds inflicted to the head region (28.7\%) were localized in the relatively small area. Significantly fewer wounds were recorded on extremities $(89 ; \mathrm{f}=6.531, p<0.05)$, and neck $(87 ; \mathrm{f}=7.398, p<0.01)$, and in the abdominal region $(72 ; \mathrm{f}=15.965, p<0.01)$. Bites to scrotum, penis, perianal area or mammary gland were rare. In the first period under study, $58 \%$ were single injuries, and $42 \%$ multiple wounds, in the second period, 69 and $31 \%$, respectively. Furthermore, 29 and 35 dogs in the two periods that were treated later than 24 hours after the incident, had complications such as abscesses and phlegmona. In the first period, one dog died, and in the second period four animals died and one was euthanized as a consequence of injuries.

\section{Discussion}

The seasonal cycle of dog bites was very similar in the two 2-year periods under study. The incidence of dog bites administered to other dogs culminated in summer months, similar to findings of Roll and Unshelm (1997) and others. However, the records of our Small Animal Clinic do not indicate the site of the conflict (in private locations or on streets and side walks, in parks etc.) so that it can only be assumed that these incidents happened outside home during walks similar to the report by Roll and Un s helm (1997). Neither do we know whether the dog conflict was of a household type (dogs of one household; Sherman et al. 1996) or between strange dogs.

The majority of victims in our set of dogs belonged to small and large breeds; fewer toy, medium and giant breed dogs were injured (it can be assumed that toy breed dogs may be protected by the owners more carefully, and giant breed dogs may be on leash more often).

In our study, males were almost two and half times more often (i.e. $69.5 \%$ vs. $30.5 \%$ ) victims of aggression than females. In a similar study S hamir et al. (2002) found $71 \%$ male (99\% of them intact) and $29 \%$ female $(58 \%$ of them intact) bite victims. A similar proportion, namely $78 \%$ males and $22 \%$ females involved in animal interaction resulting in injury, was also reported by Kolata et al. (1974) though this interaction included other animals as well. Our results show slightly higher numbers than those reported in the study of Roll and Unshelm (1997). In this context, it is interesting to note that some authors found aggressivity of females to be lower (Serpell and Jagoe 1995; Willis 1995; Landsberg and Ruehl 1997; Overall 1997). Females were found to initiate aggression to dogs in the same household more often than males, whereas more male dogs attacked nonhousehold dogs (Sherman et al. 1996). Bites to humans were administered in $85 \%$ by male dogs in a study of 146 patients treated (Shewell and Nancarrow 1991).

Ontogeny of aggression (Serpell and Jagoe 1995) is well documented by the age distribution of aggression victims in our study (Fig. 1). The number of bitten dogs declined with advancing age. The highest incidence of bite wounds was in one- and two-year-old animals. Although the age range from 6 months to 12 years is given by Griffin and Holt (2001), and 2-7 years by Shamir et al. (2002), no age distribution for bitten dogs is mentioned so that comparison with our data is not possible. Similar ages were recently reported also for biting dogs (Guy et al. 2001a). From our data it is not possible to conclude whether the structure of the dog population kept in the country or age-related confrontation experience gained in fights, or changes in relations of owners to their dogs are the underlying causes of this fact. Kolata et al. (1974) found the median age of injured dogs to be 1.9 years, practically the same age as in our study, and they suppose that young dogs learn to cope with the hazards of their environment (including animal interactions) through experience. Moreover, the early social experiences and interactions with humans and other dogs may predispose dogs to avoidance and fearfully aggressive behaviours (Appleby et al. 2002).

Location of the wounds suggests that the victims defended themselves actively (thorax and head wounded most frequently, followed by other body areas, see Table 4). Similar results were reported by Kolata et al. (1974), Griffin and Holt (2001) and Shamir et 
al. (2002). The fraction of multiple injuries in our study was higher than that reported by Kolata et al. (1974). The distribution of wounds on the head is very interesting: more than one fourth of injuries to the head region were placed in a relatively small area of auricles and eyelids. Less frequently forelimbs and neck region were injured. In reports on dog bites administered to humans, children or adolescents (and mostly male) were bitten, and predominantly injured areas were the nose and the auricles (Rettinger and Reichensperger-Goertzen 1995; Scheithauer and Rettinger 1997). In another study the hand, face and neck location were attacked more frequently in children compared with adults (Freund et al. 1997). B orud and Friedman (2000) report of 6568 dog bites to humans in New York in 1998 with the upper extremities and face predominantly affected.

Differences in dog aggression are sometimes ascribed to breeds (Scott and Fuller 1965; Hart and Hart 1985; Hart and Miller 1985; Coppinger and Schneider 1995; Hart 1995; Willis 1995; Famula 2001; Houpt and Willis 2001; Oberbauer and Sampson 2001). This idea is widely accepted in the public although it lacks scientific background. Dogs had been selected not only for morphological traits such as the size, shape, or coat but also for behaviour such as that of herding and sports (Sherman et al. 1996). Nevertheless, aggressive behaviour is also determined by previous experience of the dog (Serpell and Jagoe 1995), especially by interactions between the female and her offspring at the time of weaning (Wils s on 1985). It undergoes individual development and the act of aggression may be determined by concrete circumstances. Such information cannot be extracted from our data since they only provide records about the victims. Moreover, the number of wounded and surgically treated dogs is a function of their proportion of the entire dog population. This proportion is variable, and dependent, for example, on the type of housing of the owners: in urbanized environment, in high rises, relatively more toy breed and fewer giant breed dogs are kept than in rural areas and family houses with gardens (Baranyiová and Holub 2001).

The basic problem with quantification of intraspecies aggression in dogs is that the mutual attacks are often regarded by owners as a mere nuisance that does not require qualified veterinary assistance. The majority of dog bites administered to family members remains unknown as well (Guy et al. 2001abc). Veterinary clinics provide data only about those cases in which assistance had been sought (B eaver 1994). Therefore the frequency of dog bites reported by veterinarians is lower than the real number of such incidents. The proportion of wounds treated after animal interactions accounts for $10 \%$ of all wounds treated in dogs in the study of Kolata et al. (1974). In our set of patients, 6732 dogs were treated in 1998 and 1999 at the Small Animal Clinic; 337 (5.0\%) were bitten by other dogs, and 25 dogs ( $7.4 \%$ of these) suffered trauma serious enough to require hospitalization. Dog attacks may vary in intensity; healing of the wounds may require long-time professional attention. It should be also considered that, e.g. in the USA about four fifths of dog owners seek veterinary help at least once a year for their canine companions (Tro u m an 1988). The situation in this country is not known - we do not even know how many dogs are kept in Czech households (Baranyiová et al. 1998, 1999; Baranyiová and Holub 2001). This is one factor limiting the general validity of data about the problem of our interest, intraspecies aggression of dogs.

The number of patients treated for bite injury between the two periods under study increased significantly by $37 \%$, and it seems to reflect the increasing popularity of large breed dogs in this country. It may also indicate that public awareness of the problem that would result in seeking professional help or advice has not changed between the first and the second period under study. Another interesting fact is that no neutered animal was reported among these patients in contrast to other countries where neutering animals of both sexes is common practice (Sherman et al. 1996; Guy et al. 2001ab) to prevent unwanted 
reproduction and alleviate some behavioural problems. In conclusion, our data suggest that for dogs the risk of being wounded by a conspecific differs between seasons and depends on a dog's age, sex and body size.

\section{Vnitrodruhová agrese a rány kousnutím u psů v České republice}

Ze záznamů o psech ošetřených na Klinice malých zvířat, oddělení chirurgie FVL FVUB jsme sledovali výskyt ran kousnutím, které byli výsledkem agresivních střetů mezi psy. Srovnávali jsme údaje z let 1989-90 (246 záznamů o střetech psů) a z let 1998-99 (337 záznamů). Počet případů kousnutí se v průběhu roku měnil, a to tak, že nejvyšší byl ve druhém (n=149) a třetím (n=193) kvartálu. V prvním kvartálu bylo ošetřeno 119 a ve čtvrtém 122 pacientů. Celkový počer obětí pokousáni vzrostl $(p<0,01)$ mezi 1 . a 2 . sledovaným údobím. Většina jich patřila $\mathrm{k}$ malým $(37,9 \%)$ a velkým $(24,8 \%)$ plemenům; poté následovala plemena střední $(19,0 \%)$, obří $(11 \%)$ a trpasličí $(7,3 \%)$. Nejvyšší byl podíl obětí pokousání 2 let $(15,6 \%)$, a poté se s přibývajícím věkem zmenšoval až na $1 \%$ pokousaných psů ve věku 11 let. V 571 případě bylo zaznamenáno pohlaví pokousaného jedince; z toho bylo jen 176 fen (30,3\%), ale 405 psů (69,7\%). U 503 zranění byla známa lokalizace ran: velký počet kousnutí byl směřován na hrudník $(26,6 \%)$ a hlavu $(25,3 \%)$, tedy na přední část těla. Více než čtvrtina ran na hlavě byla v relativně malé oblasti kolem očí $(28,7 \%)$. Méně ran bylo na končetinách $(17,7 \%)$, krku $(17,3 \%)$ a v oblasti abdominální (14,3\%). Z těchto údajů vyplývá, že riziko pokousání jiným psem se mění v průběhu roku a závisí na věku, pohlaví a velikosti zvířete.

\section{Acknowledgements}

Thanks are extended to U. A. Luescher for critical reading of the manuscript and for helpful suggestions.

\section{References}

APPLEBY, DL, BRADSHAW, LWS, CASEY, RA 2002: Relationship between aggressive and avoidance behaviour by dogs and their experience in the first six months iof life. Vet. Rec. 150: 434-438

ASKEW, HR 1997: Behandlung von Verhaltensproblemen bei Hund und Katze. Parey Verlag, Berlin. VII and 372 p.

AZRIN, NH, HUTCHINSON, RR, MCLAUGHLIN, R 1965: The opportunity for aggression as an operant reinforcer during aggressive stimulation. J Exper Anim Behav 8: 171-180

BARANYIOVÁ, E, HOLUB, A, ERNSTOVÁ, M 1998: Dogs in the Czech Republic. In: Ochrana zviŕat a welfare 1998, Conference Proceedings. VFU Brno, pp. 11-12

BARANYIOVÁ, E, HOLUB, A, JANÁČKKOVÁ, B, ERNSTOVÁ, M 1999: Dogs in Czech households. Proceedings of the $33^{\text {rd }}$ International Congress if the ISAE (KE Bøe, M Bakken BO Braastad, Eds), NLH, Agricultural University of Norway, p. 156

BARANYIOVÁ, E, HOLUB, A 2001: Housing affects behaviour of domesticated dogs. Proceedings of the $35^{\text {th }}$ International Congress of the ISAE. (JP Garner, JA Mench, SP Heekin, Eds), University of California, Davis, p. 50 BEAVER, BV 1983: Clinical classification of canine aggression. Appl Anim Ethol 10: 35-43

BEAVER, BV 1993a: Canine aggression. Appl Anim Ethol 37: 81

BEAVER, BV1993b: Profiles of dogs presented for aggression. J Amer Anim Hosp Assoc 29: 564-569

BEAVER, BV 1994: Owner complaints about canine behavior. J Am Vet Med Assoc 204: 1953-1955

BLACKSHAW, JK 1991: An overview of types of aggressive behavior in dogs and methods of treatment. Appl Anim Behav Sci 30: $351-361$

BORCHELT, PL 1983: Aggressive behavior of dogs kept as companion animals: Classification and influence of sex, reproductive status and breed. Appl Anim Ethol 10: 45-61

BORUD, LJ, FRIEDMAN, DW 2000: Dog bites in New York city. Plastic and Reconstructive Surgery 106: 987990

COPPINGER, R, SCHNEIDER, R 1995: Evolution of working dogs. In J. Serpell (Ed.): The Domestic Dog, its Evolution, Behaviour, and Interactions with People. Cambridge University Press, Cambridge. pp. 21-47

FAMULA, TR 2001: Genetics of quantitative traits and improvement of dog breeds In: A. Ruvinsky (Ed.): The Genetics of the Dog. CABI Publishing, Wallingford-New York, pp. 467-503

FRASER, D, RUSHEN, J 1987: Aggressive behavior. Vet Clin North Amer Food Anim Pract 3: 285-305 FREUND, HK, COLONES, JLL, SAINZ, CS, VIDAL, PH 1997: Animal bites. Rev Clin Esp 197: 560-563

GRIFFIN, GM, HOLT DE 2001: Dog-bite wounds: bacteriology and treatment outcome in 37 cases. J Am Hosp Assoc 37: 45-460 
GUY, NC, LUESCHER, UA, DOHOO, SE, SPANGLER, E, MILLER, JB, DOHOO, ITR, BATE, LA 2001a: Demographic and aggressive characteristics of dogs in a general veterinary caseload. Appl Anim Behav Sci 74: $15-28$

GUY, NC, LUESCHER, UA, DOHOO, SE, SPANGLER, E, MILLER, JB, DOHOO, ITR, BATE, LA 2001b: Risk factors for dog bites to owners in a general veterinary caseoload. Appl Anim Behav Sci 74: 29-42

GUY, NC, LUESCHER, UA, DOHOO, SE, SOANGLER, E, MILLER, JB, DOHOO, IR, BATE, LA 2001c: A case series of biting dogs: characteristics of the dog, their behaviour, and their victims. Appl Anim Behav Sci 74: $43-57$

HART BL 1995: Analysing breed and gender differences in behaviour. In In J. Serpell (Ed.): The Domestic Dog, its Evolution, Behaviour, and Interactions with People. Cambridge University Press, Cambridge. pp. 65-77

HART LA 1995: Dogs as human companions. In J. Serpell (Ed.): The Domestic Dog, its Evolution, Behaviour, and Interactions with People. Cambridge University Press, Cambridge. pp. 161-178

HART, BL, MILLER, MF 1985: Behavioral profiles of dog breeds. J Amer Vet Med Assn 186: 1175-1180

HART, BL, HART, LA 1985: Selecting pet dogs on the basis of cluster analysis of breed behavior profiles and gender. J Amer Vet Med Assn 186: 1181-1185

HETTS S, CLARK JD, CALPIN JP, ARNOLD CP, MATEO, JM 1992: Influence of housing conditions on beagle behaviour. Appl Anim Behav Sci 34: 137-155

HOUPT, KA, WILLIS, MB 2001: Genetics of Behaviour. In: A. Ruvinsky (Ed.): The Genetics of the Dog. CABI Publishing, Wallingford-New York, pp. 371-400

KOLATA, RJ, KRAUT, NH JOHNSTON, DE 1974: Patterns of trauma in urban dogs and cats: a study of 1000 cases. J Amer Vet Med Ass 164: 499-502

LANDSBERG, GM, RUEHL, WR 1997: Geriatric behavioral problems. Vet Clin North Amer Small Anim Pract 27: $1537-1559$

LEWIS, LD, MORRIS, JR ML, HAND, MS 1987: Small Animal Clinical Nutrition. III. Ed. Mark Morris Assoc., Topeka, Kansas $3^{\text {rd }}$ Edition, $4^{\text {th }}$ printing, 1992, p. 6-6

LOCKWOOD, R 1995: The ethology and epidemiology of canine aggression. In: The Domestic Dog, its Evolution, Behaviour, and Interactions with People. Cambridge University Press, Cambridge. pp. 131-138

LORENZ, K 1966: On Aggression. Methuen, London

MERTENS, PA, DODMAN, NH 1996: The diagnosis of behavioral problems in dogs, cats horses, and birds: Characteristics of 323 cases (July 1994 June 1995). 1. Dog. Kleintierpraxis 41: 197-206

OBERBAUER AM, SAMPSON, J 2001: Pedigree analysis, genotype testing and genetic counselling. In: A. Ruvinsky (Ed.): The Genetics of the Dog. CABI Publishing, Wallingford-New York. p. 461-485

OVERALL, KL 1997: Clinical Behavioral Medicine for Small Animals. Mosby - Year Book Inc. St. Luis. 544 p.

RAPLEY, JH, LAWRENCE, WT, WITT, PD 2001: Composite grafting and hyperbaric oxygen therapy in pediatric nasal tip reconstruction after avulsive dog-bite injury. Ann Plast Surg 46: 434-438

RETTINGER, G, REICHENSPERGER-GOERTZEN, C 1995: Dog-bite injuries of the face. HNO 43: 159-164

ROLL, A, UNSHELM, J 1997: Aggressive conflicts amongst dogs and factors affecting them. Appl Anim Behav Sci 52: 229-242

SCHEITHAUER, MO, RETTINGER, G 1997: Bite injuries in the head and neck region. HNO 45: 891-897

SCHOENING B.: Dangerous Dogs in Germany - and how to define "normal aggression". Proc. 3 rd Int.Congress on Veterinary Behavioural Medicine (Ed. KL Overall et al.) Vancouver, 7-8 August 2001. Univ. Fed. for Animal Welfare, UK pp. 96-99

SCOTT, JP, FULLER, JL 1965: Genetics and the Social Behavior of the Dog. University of Chicago Press. Chicago

SERPELL, J 1995a: Introduction. In J. Serpell (Ed.): The Domestic Dog, its Evolution, Behaviour, and Interactions with People. Cambridge University Press, Cambridge. pp. 1-4

SERPELL, J 1995b: From paragon to pariah: some reflections on human attitudes to dogs. In J. Serpell (Ed.): The Domestic Dog, its Evolution, Behaviour, and Interactions with People. Cambridge University Press, Cambridge. pp. 245-256

SERPELL J, JAGOE, JA 1995: Early experience and the development of behaviour. In: Serpell J (Ed.): The domestic dog, its evolution, behaviour, and interactions with people. Cambridge University Press, Cambridge. p. $79-102$

SHAMIR, MH, LEISNER, S, KLEMENT, E, GONEN, E, JOHNSTON, DE 2002: Dog bite wounds in dogs and cats: a retrospective study of 196 cases. J Vet Sci A49: 107-112

SHERMAN, CK, REISNER, IR, TALIAFERRO, LA, HOUPT, KA 1996: Characteristics, treatment, and outcome of 99 cases of aggression between dogs. Appl Anim Behav Sci 47: 91-108

SHEWELL, PC, NANCARROW, JD 1991: Dogs that bite. Br Med J 303: 1512-1513

TROUMAN, CM 1988: Cat owners and their use of veterinary services. J Amer Vet Med Ass 193: 1217-1219

WILLIS, MB 1995: Genetic aspects of dog behaviour with particular reference to working ability. In: In Serpell J (Ed.): The Domestic Dog. Its Evolution, Behaviour, and Interactions with People. Cambridge University Press. Cambridge. p. 51-64

WILSSON, E 1984: The social interaction between mother and offspring during weaning in German Shepherd Dogs: individual differences between mothers and their effects on offspring. Appl Anim Behav Sci 13: 101-112 